\title{
Reflection of Pay Failed Debtor Behavior Based on Weton Based Characters
}

\author{
Dwi Rendra Adi Putrawijaya ${ }^{1 *}$, Basuki $^{2}$ \\ ${ }^{I}$ Postgraduate Student, Master of Accounting, Department of Economics and Business, University Of Airlangga, \\ Indonesia \\ ${ }^{2}$ Professor of Accounting, Department of Economics and Business, University Of Airlangga, \\ Indonesia
}

*Corresponding Author: Dwi Rendra Adi Putrawijaya, Postgraduate Student, Master of Accounting, Department of Economics and Business, University Of Airlangga, Indonesia

\begin{abstract}
:
Purpose: The main objective of this research is to know the characters as seen from Weton debtor in relation to the formation of Loan Loss Provision (LLP).

Design / Methodology / Approach: This study is a qualitative research because it does not use statistical methods in the search forthe problem to be solved. This study apply data mining methods tofind the meaningof theWeton sourcetriangulation method is done by interviewing the experts, interview respondents, and librarian studies. The source of this research data is in the form of words and behavior obtained from interviews with debtors and pawukon experts. Print media and documents also support the main data source.

Results: In this study it can be found that weton has relevance to the character of an individual. This is because weton is actually also a matter that is prepared scientifically and through a long-term process. On the character, it also has an impact on the actions of someone who in this study is a debtor. Based on the results of interviews and literature studies, researchers see that there are direct and indirect impacts that can lead to credit defaults.
\end{abstract}

Authenticity / Value: This study uses Spranger theory as the basis for the existence of Pawukon science, especially weton which is believed by the people of Java and the theory of individual loan loss provisions in relation to the characters who are able to form LLP.

Keywords: Reserves for Impairment, Character, Weton, Interpretative.

\section{INTRODUCTION}

According to the Law of the Republic of Indonesia number 10 year 1998 explained that the Bank is the agency that acts as an agency intermediaryinstitution that mediate between the surplus and deficit units by obtaining funds from the public in the form of deposits such as savings, time deposits, and current accounts as well as channeling the funds in the form of credit (Law No. 10 of 1998).According to Kasmir (2012) unit surplus in this case can be interpreted as parties who have excess funds or cash flows such as individuals, government agencies, and corporations. So that to maximize its income and no idle cash, the funds are kept at the Bank and get interest income.

The Bank will manage the funds obtained from surplus units so that the Bank can earn interest income and be able to cover the cost of funds issued to its customers on deposits provided to the Bank. In addition to interest income, the Bank also receives fee-based income forservices provided by the Bank to its customers (Thamrin and Tantri, 2012). According to Bischof etal. (2016) bank is a highly regulated institenution isan institenution that is bound by many rules issued by some other party who is authorized to regulate with the aim of overseeing performance and operations of the Bank.

The Bank has procedures and implementation guidelines that must be obeyed by credit analysts and prospective borrowers. The need for procedures and guidelines for the implementation so that in granting credit still pay attention to the precautionary principle and to mitigate credit risk if the loan is in default installments or collections level 3 (three), 4 (four), and 5 (five). 
Credit analysis process based on the several theories such as Principles 6C namely Character, Capacity, Capital, Collateral, ConditionsOf Economy, and Constraintexpressed by Kashmir (2012). Anothertheorythat underliestheimplementationof credit analysis is the $7 \mathrm{P}$ principle which consists of Personality, Party, Purpose, Prosepct,Payment, Profitability, Protection. If you look at these principles, it always begins byunderstanding the character or personality of the prospective debtor before undergoing the next stageof analysis. Five of the 6 (six) aspects of credit analysis can be quantified or validated on the basis of data obtained directly from the source and other relevant third parties in providing financial data (Abdou et al, 2011). While the character aspect is a subjective aspect, because it is necessary to assess the extent to which characters such as honesty and integrity borrowers. Phenomena that occur in the field where credit analysts only perform historical analysts, namely believing in the debtor installment behavior that has occurred for the old debtor who will apply for more credit. For new debtors, credit analysts will conduct small interviews with neighbors, business colleagues, and related parties. However, credit analysts do not carry out in- depth and difficult analysis to predict the behavior, character, and nature of the applicant because it is a basic human nature to always expose good things and tend to cover up the shortcomings. In addition, even though the bank already has scoring credit but the basis for determining the scoring still does not accommodate other sourcescomprehensively (Abdou et al, 2011). Accordingto Carrizosa and Ryan (2016) that research activities or examination of information provided by prospective borrowers relating to borrowers of prospective borrowers is very necessary to convince the bank in its credit decision and see the willingness and ability of prospective borrowers to pay installments and repay their debts.

Character is a personality that grows in individuals formed from various influences. In psychology there is the Spranger Theory which states that there are 2 (two) kinds of spirits (Geist) in the human personality namely subjective spirits or individual spirits contained in each human and objective spirit or supra-individual spirit or culture that is the spirit of all humanity, which in its focus is a culture that has been incarnated and developed for centuries with individual humans (Spranger, 1928). Cultural value will disappear if if humans as individuals do not support it and live it. Humans accept the existing culture and develop that culture with new creations.

Weton is the result of the creation of Javanese community-individuals which is a form of objective or cultural spirit that has received general recognition. Weton can affect individuals who live in social confusion where the weton principle has been developed for centuries. For this development based on values and norms, weton for Javanese people can interpret the values of human character and behavior.The cultural value in the form of weton can be lost if Javanese people as individuals who create it no longer have an objective spirit of the weton and do not support it and live it.

Therefore, from the background previously explained there are problems that cannot be measured by character aspects in the credit analysis process and the data obtained are not objective because credit analysts are not able to comprehensively explore the character of prospective borrowers. During this time information related to the nature, character, and behavior of prospective borrowers is obtained from the surrounding community and the community tends to provide good information. In addition, the method of credit analysis that applies so far has been born from a process of thinking that has capitalist ideology. Therefore, in thisstudy theauthors focusedon theanalyst is clicking and wheezing debtor character is seen from Weton and how to link these characters if they relate to accounts payable, especially with the Bank, so that will affect the LLP that will be established by the bank.

This study is a qualitative research because it does not use statistical methods in the search for an swear on the problem to be solved. This study apply data mining methods to find the meaning of these Weton through source triangulation method is done by library research (library research), interviews of experts, and interviews to the debtor. The data source of this research is in the form of words and behavior obtained from interviews with debtors and pawukon experts. Print media and documents also support the main data source.

In this study it can be concluded that weton has relevance to the character of an individual. This is because weton is actually also a matter that is prepared scientifically and through a long-term process.On the character, it also has an impact on the actions of someone who in this study is a debtor. Based on the results of interviews and literature studies, researchers see that there are direct and indirect impacts that can lead to credit defaults. 


\section{LITERATURE REVIEW}

\subsection{Weton}

Weton ontologically is a real thing and has a very high level of accuracy and precision. According to Kejawen science, all mechanisms of life and human activities can be calculated with weton in order to have compatibility with someone. This can be in the form of a marriage contract day which cannot be done on "tibone" day ancestors or the day of death of ancestors such as biological mother's father from parents and from in-laws.

According to Kejawen, the epistemological dimension answers how the weton is obtained. In the past the ancestors did "tirakat" or the process of meditation and made observations of the behavior of human life or the science of titenan. Then from the results of the observation method, the ancestors poured it in notes called the Javanese fiber book. These notes explain the meaning of weton and its explanation of character, fortune, soul mate, fortune, and so on. Observations and knowledge of the titenis carried out continuously and for generations by observing birthdays and market days such as kliwon, wage, pon, pahing, and legi. The science of the titen is part of the journey of life and experiences of ancestors who observe human behavior based on birth day. As a science or theory, weton has an axiological dimension that is about the designation and how the implementation of the science. Basically science is created to help human activities and life and to solve problems (Kattsoff, 2004). In Javanese society, weton is used for various things such as determining whether prospective husband and wife are appropriate or not and determine the day of the marriage contract of the prospective substitenute. In addition, there is a Wetonfast, which is fasting on Weton Day. The meaning of fasting is that it can provide spiritual enlightenment and resist lust from worldly life.

\subsection{Allowance for Impairment Losses (LLP)}

Basically, LLP is formed from financial assets in the form of loans provided that initial recognition is measured at fair value plus transaction costs that are directly attributable to the financial asset (Wall and Koch, 2000). Measurements after initial recognition of the loans provided are measured at cost amortized using the effective interest rate method. LLP will be formed if financial assets such as loans given cannot be billed or experience credit quality nonperformingloans withcategories of 3 (three), 4 (four),and 5 (five) and experiencing impairment (Onali and Ginesti, 2015). The Bank will evaluate each specific period whether there is a decline in the value of financial assets at the reporting date accompanied by supporting objective evidence.

Banks can use kind of manners to assess impairment, either individually or collectively. In choosing and using an impairment evaluation technique, banks need to consider the analysis of costs and benefits and the availability of historical information and data (Ozili et al, 2017). Evaluation of impairment is not only based on an approach or standard method (prescriptive rules / formulas) but also based on experienced credit judgments by parties who have the competence and authority considering the experience of historical losses and observable data that are limited or may not be fully relevant to current conditions. Evaluation of impairment can be done in 2 (two) methods including:

\subsubsection{Individually}

Impairment evaluation is done by calculating the difference in the loss of the present value of the estimated cash flow that will come with the Listed Value through DiscountedCash Flow. Individual LLP is calculated by considering and predicting the ability of payments from debtors in the future (estimate cashflow).

\subsubsection{Collectively}

Collective impairment evaluation, whereby the LLP is calculated on the level of historical loss the Bank has experienced on assets that have credit risk characteristics similar to the group's credit risk characteristics through the calculation of statistical data models using the Probability of Default parameter, namely the percentage rate the likelihood of a debtor failure to fulfill its obligations is measured based on the Migration and rollrateanalysis approach. Individual evaluations require substantial costs, time, and effort, so the bank will classify several LLP into collective groups by considering the following :

- Calculation LLP collectively calculated using historical datas;

- Banks are required to specify in the calculation LLP bucket Collective; 
- Banks must determine Peer Group in accordance with the characteristics of each Bank;

- Banks must provide restrictions on the borrowers with significant debtors calculated individually;

- Banks are required to periodically review the percentage of LLP.

In its application, banks must calculate in several methods, then decide the formulation that is most appropriate to the conditions of each bank. Therefore, LLP is a credit risk management tool used by banks to reduce expected losses on bank loan portfolios.

\section{RESEARCH METHODS}

This research is qualitative, because the study did not use statistical methods in the search for answear on the problem to be solved. Similar to the research Sawarjuwono and Kadir (2004), this research method to apply data mining methods to find the meaning of these Weton throughsourcetriangulation method is done by library research (library research), interviewsof experts, and interviews to the debtor. The data source of this research is in the form of words and behavior obtained from interviews with debtors and pawukon experts. Print media and documents also support the main data source. Research using literature is literature-based research model as an object of study and conduct interviews to people who are considered experts in thescience pawukon. Researchers use this approach becauseresearch is still limited to researching related topics discussed by researchers.

One method in this study needs to be conducted an interview, so the author will conduct interviews through meetings with informants who are considered experts and debtors in a place agreed between the researcher and the informant. Then the researcher will conduct an interview with the informant. It is estimated that the interview time is approximately 30 (thirty) minutes. The informants who are the object of interviews from the debtor and conducted at the home or place of business of the debtor. In addition to interviews with debtors, the author will also conduct interviews with pawukon experts, including:

- Mrs. Nia, she is a librarian at the Raditya Pustaka Surakarta Museum where the museum is the oldest museum in Indonesia and has original archives, documents, and writings from ancient Javanese relics written in lontar.

- Mrs. Endang, she is a Mpu Tantular Sidoarjo librarian, she has a background in Indonesian literature. Everyday he often fills seminars on Indonesian literature.

- Mbah Gudel, he is the administrator of the Bung Karno library in Blitar and has a background in philosophy from Gajah Mada University (UGM).

In this study the object of research is a database of debtors who have experienced default or the condition of collectability of non-performing loans. From the debtor database, the researchers focused on the character and character of the debtor that can be seen from each of the different debtors.Dataextraction in this study uses library method or literature study and interview method.

In this study also carried out primary data extraction obtained from interview activities to informants who understand the science of pawukon. The research will take several informants who usually work as historical librarians of Javanese society or pawukon science activists. The researcher also took 8 (eight) informants from debtors who experienced default. The debtor interviewed has the most weton in case of default. This is done to get a comparison between the answers of one informant and another in one category. The information from the interview will be used to confirm, compare, and interpret the information obtained from the analysis of print media content and the answers of one informant to another.

\section{RESUltS AND DisCUSSION OF RESEARCH}

\subsection{Pawukon Science Theory}

Based on the interview with Mbah Gudel as the Bung Karno Museum library librarian, explained Weton as valence, strength, legacy from certain days based on long-term experimental results, but there was no documentation and was not written in scientific research. In an interview conducted on May 5, 2018 at the residence of Sultan Agung number 9, East of Tanah Gebang, he revealed that:

"This weton means that the Javanese have a valence. Weton, for example, that Sunday 5 (five), then again Monday 4 (four), Tuesday 3 (three), Wednesday 7 (seven), and so on. It is like an 
atom, it's valence, dignity, strength. Now that's the science of the titen, it's been an experiment that has been for years, now Javanese science is niteni, now niteni is experimental. So it cannot be said that it is illogical, it cannot, because of experimentation. But because the experiment is not written in the form of research like Westerners, there is an analysis and so on. Finally, that's all. The delivery is not written, the delivery is through speech, messages to students, messages to children, grandchildren. Well finally depends on the ability to catch, now here. But by the ancestors who could write, finally it was stated in the Centini book, there was the Sastra Gending book, Sabdo Pandito, there was a Betaljemur book, well finally gathered there. But sometimes what is collected is just how we absorb which decides match, which is not. Depends on our ability to filter, so." (Mbah Gudel)

Based on what was conveyed by Mbah Gudel, it can be concluded that the science of pawukon in its preparation has actually been through a series of observations made by ancestors in a very long period of time or using the method of niteni (remembering), but in the past there was still no set of research tools such as Statistical Package for the Social Sciences (SPSS), Partial Least Square (PLS), and others that are used today.

Generally this knowledge is widely used by a small number of Javanese tribes. But Balinese people are still very strong in the use of weton, pawukon, and wewaran. As with the original purpose of their Weton, use Weton calculation and beheading another calendar used to look for the good in the ceremony (wedding, cremation particularly by the Hindu community of Bali). But along with the development of religion, science and technology, the useof weton calculations increasingly receded and was ruled out. Likewise, the study of weton cultural heritage is very little pursued. Today the use of weton is not limited to conventional purposes such as weddings, thanksgiving and arranged marriage. Intellectual society increasingly views weton as a scientific heritage. Considering the complexity of the science of weton, this science is used in several fields of science both related to human character and natural prediction. At this time studies on weton have been widely developed in various disciplines .

Besides being used in the discipline of psychology, the science of weton and prey institution is also used in agricultural science. BMKG's often inaccurate predictions cause people from the agricultural faculty to try other alternatives by studying the Javanese calendar. One of them is a party from Duta Wacana University which uses the basic knowledge of weton in research on agriculture. This is based on a statement delivered by Ms. Nia, namely:

"Yesterday it was from the Duta Wacana university, it was agriculture, so now the calculation has also started using this. Because some time ago the BMKG-style calculations were missed. That's for the universe like this, pronoto mongso like that misses it, he said. So they want to make Javanese agricultural research." (Mrs. Nia)

\section{RESULTS AND DISCUSSION}

\subsection{Debtor with Weton Wednesday Pon}

Referring to the financial side, from various sources as in books by Doyodipuro (2016), Wijoto (1972), and Sudharta(2001) stated that they were born on Wednesday Pon is generally easy to find fortune. Generally they are have abundant fortune and lack of clothing and boards. This is in accordance with their diligent and hardworking nature, and does not rule out the possibility of being a leader.

Besides these positive traits, Wednesday Pon's character hasseveralnegative traits. First,on generally they like to be praised and easily offended (Wijoto, 1972). The character, like expecting adulation makes them so extravagant that does not have the priority in financial affairs. This is in accordance with the statement from Mrs. Endang, namely

\footnotetext{
"Influenced by the Granary star, the action of the Earth is in the appearance of his socially polite, careful, alert, virtuous, good sustenance, clever sociability and easy to find friends, any work can, not easily discouraged, endure the test, diligent in the work he faces, it's just that showing off, both intelligence and wealth, likes to be praised but it's easily offended." (Mrs. Endang)
}

The author also conducted an interview with Judy's business partner. This was done because the interview with the relevant debtor did not provide real information. The business partner,commonly known as Mami, said that: 
"Oh yeah, judy is a rice slice business, it's now a bankrupt business, because the behavior itself is strange. So, now, Judy used to be his religion, Catholic, well, then where did he come from, suddenlylearning about the religion of Islam continued to become converts. Well, strangely, studying Islam might be moreover, he was sort of like a fanatic. Since becoming a convert, he built a mosque directly at the business place, in the corner near the warehouse. Then the employee was told to pray when it was time to pray. His wife was also forced to pray but never wanted to. Until now his wife is still a Catholic not yet become Islam. " (Mami)

Weton Wednesday pound from the debtor in this study was dominated by myBala and Tolu . To avoid bias in summing up the character of the debtor who was born on Wednesday Pon, the difference in the character that may arise due to differences in the dominant wuku also considered. Just like someone's character based on weton, the difference in character of someone based on my sex also has good and bad characteristics. Mbah Gudel M ccording to sources, people born in wuku Bolo / Bala carries the worst character compared to other women .

One of the respondents, Judy Sukardjo a debtor who was born in Weton Pon with wuku Bala. Wednesday Pon's birth on BalaWuku has paringkelan Panngiron. Paringkelanis derived from the word "fragel" which means when it is weakest, silent, or defeated. Atfirst, paringkelan which is a fragment of time consisting of 6 (six) days (sadwara) is used for calculation of daily activities. In its development, the paringkelan was also used to predict the influence of the journey of human life and human nature that was born in the fragile. Paringkelan can also be interpreted as a moment of bad luck that falls on certain days .

People born with the frankel paningron (mina) have pengapesan like fish, easily provoked by others. Excluded from Gudel (2015), fragile Paningron brings diligence, agility and lots of sense.However, those born with this vulnerel have a tendency to cheat.

The author also conducted interviews with correspondents on behalf of Nonong Holiyatin who had weton Wednesday Pon as well. The author asks why the debtor is unable to pay and finds an answer if the debtor has cervical cancer. Here's the story of the debtor.

When the author makes a visit, the debtor is willing to make payment of credit arrears and it is agreed that payments are made every month on a regular basis. The debtor also signs a call report which is an objective proof of the promise to pay. Negotiations on the amount of installments were initially offered at $\mathrm{Rp} 2,500,000.00$, but the debtor felt objected and requested an installment of $\mathrm{Rp}$ 1,500,000.00.Laughing, the debtor delivered:

"Don't do it . Just Rp 1,500,000.00 first, don't be forced, if I can't afford it, it's impossible to say that, later if there is a fortune I add Rp. 2,500,000.00. I've disappointed you a lot. Don't want to promise again "

Time goes on, when there is time to billing the following month, the credit billing staff provides information that:

"When I collect in May, I go to his shop, then the one who leaves her husband. He said that his wife (Nonong) had been exhausted, could not be found. He said that reason. So, there is no collection of credit arrears. Later the LLP will be added. Then I asked the pedicab driver who was standby from the front of his shop from the morning he said that from the morning the wira wiri was healthy and healthy like that of the Nonong.

\subsection{Debtor with Weton Saturday Pon}

In terms of fortune, this birth is not less clothing and food . Like people with the birth of Wednesday Pon, the birth of Saturday Pon also includes brave people who have helped him, which in this study is the bank as a creditor. Besides being forgiving and generous, they also have arrogant nature, so even though they have many friends, they also have many enemies and are often slandered.

In accordance with the statement of MbahGudel that "analyzing theperson's character is not enough just to use Weton alone", thus wuku and paringkelan of the debtor is also considered. The debtor with weton Saturday Pon in this study was dominated by wuku Pahang, wuku Wugu and Galungan. Wuku Pahang has Paningron or fragilemina, while Saturday Pon wuku Wugu have ringkel Aryang orringkel jalmo, as well as Saturdays pound wuku Galungan with ringkel Uwas or ringkel book.

One of the debtors with Weton Saturday Pon Wuku Wugu is Bambang Sumantri who has UD Genteng Mulia . Debtors have a house-making business that is usually ordered by building shops and 
house construction projects. The condition of the collectability level of debtors has entered the level of 5 (five), namely traffic jam. When the author makes a visit (on the spot) and interviews, the debtor is no longer able to make delinquent payments even if given waivers. Current conditions, the debtor has tried to sell assets inherited from his parents to pay off his debt. Debtor tells:

"So the total value of the land is 3 billion rupiahs and I do not want it but I appreciate the value of my family.I asked that there's just half and I will not take everything here. I'm only half the land alone, because already there who want to buy. Finally, my brother made a decision that each plot of land was divided into six to make it easy to sell."

According to the author's observation, the debtor is sporty when conducting interviews with passionate expressions and tones especially when discussing the inheritance of his parents which will be distributed to his brothers. According to Doyodipuro (2016), the individual who had a coupon was Saturday Pon has character willing hard and enterprising work. It is often slandered and there are many friends, but there are also many enemies and people who are bullied.

The author gets information from the billing staff in accordance with what is explained by the Pakuwon book. The following is information from the billing staff regarding the debtor:

"So now the position of the debtor is already in arrears and is no longer available and unable to pay installments even though restructuring is carried out. The last time I visited there, one of the solutions was to sell collateral to pay off. Now, Mr. Bambang is forcing his brother to give him money to replace his inheritance rights. The money is planned to be made to pay off the debt to the Bank"

What is disclosed by the debtor to the credit collection staff is in accordance with his character that is concerned with his own interests which is one of the individual traits of Wugu (Gudel, 2015) . In this case the interests of the debtor deal with the Bank in terms of credit arrears.

One of the debtors with weton Pon Ponuku Galungan is Tommy Bohan. The author visits 2 times to the debtor's house and cannot meet, so the author is only able to conduct telephone interviews. When the writer asks how chronological the story is until the debtor does not pay the installments. Then the debtor Tommy Bohan answered:

" Yes, so used to it I do applying for a loan to buy a house, specifically mortgage property. I asked for an outstanding of Rp.220,000,000.00. So when I applied for credit, I was a freelance or security guard at Carrefour. Well, at the beginning of my credit, I still paid off smoothly, then Carrefour was dismantled to build a new building to become Trans Mall Jember. Because it was dismantled, the management laid off all employees including me. Then, since my livelihood from the security guard doesn't exist, finally I can't afford to pay it back now. I am still unemployed, nothing and work is odd."

According to the author's observation, the debtor on behalf of Tommy Bohan was sporty and told the author what he was. Debtors surrender and submit appropriate actions to be carried out to the Bank and do not complicate the problematic credit collection mechanism. The author observes information obtained from direct debtors and credit analysts. In accordance with the statement from Mbah Gudel that "analyzing the character of a person is not enough just by using weton ", thus the time and paringkelan of the debtor are also considered. The author investigates that Tommy Bohan has a Galungan village which according to Gudel (2015) that the wuku is symbolized by the vase of water behind and the upside-down bang, which means to do things that are disruptive and wasteful but willing to give for the sake of others. According to the debtor information there is a suitability that Tommy Bohan likes to make people happy and pleases his family. However, his character is brave by not thinking about family financial problems that result in credit defaults (Doyodipuro, 2016) . Due to the conditions experienced by the debtor, the Bank has establishedLLP amounting to Rp. 51,772, 929.00 from the initial outstanding of Rp. 220,000,000.00

\subsection{Debtor with Weton Tuesday Wage}

Weton Tuesday Wage was dominated by Wuku Wugu. This time is the 26th Wuku that is sheltered by Dewa Bathara Singajalma. This character is dominated by positive things such as being open-minded, broad-minded, polite, alert and understanding to others. Viewed from the side of the fort, this girl has an abundant fortune. 
The character of the Tuesday Wage Wuku Wugu is symbolic of a backbone that means, despite having a fortune, this person is stingy and stingy. In addition, this time is symbolized by the Anedheng Wohe Wuni Tree (Wuni is fruiting) which means that like looking for other people's attention but often disappointing people who are known. In relation to debts, the nature of stinginess and selfishness is one of the triggers of the debtors' low desire to pay debt.

Paringkelan is derived from the word "fragel" which means when it is weakest, silent, or defeated. At first, the paringkelan which is a part of time consisting of 6 days ( sadwara) is used for calculation of daily activities. In its development, the paringkelan was also used to predict the influence of the journey of human life and human nature that was born in the fragile. People born with the frankel paningron ( mina) have pengapesan like fish, easily provoked by others. According to Gudel's book (2015) Paningron's fragile brings diligence, agility and lots of reason. However, those born with this vulnerel have a tendency to cheat.

The author conducts interviews with debtors who have weton selasa wage with Wuku Pahang, and Fransel Paningron on behalf of Rofiq Fauzi and the author asks how the credit trip is chronological, then the debtor innocently tells:
"So first starting around May 2017 I took credit at Bank. I took Rp 100,000,000 and planned to make candy, then made a tobacco business with my friend. He said tobacco was good. Yes, I myself believe too much in my family. I finally gave my love and in fact the tobacco business failed "

The debtor also claimed to have lent his motorcycle before taking credit at the Bank:
"I've been on a bicycle loan and already spent Rp. 27,000,000. Then my bike was borrowed by a friend and turned out to be mortgaged. Then, I said that the bike is still in the credit period and I ask for help don't borrow too long because I use work too. Finally, I was billed continuously by the leasing party because of the credit installment. Because I was billed constantly, then I said that the bicycle was in my friend. As a result the bike was seized by the leasing party. Even though the installments are less than 9 (nine) months, they are paid off "

According to the author's observation, from the results of the interview, it was seen that the most prominent characteristic of the debtor was that it was easy to give something to someone without calculation. This is also the main factor in the occurrence of default on the debtor's credit facility, because the money that should have been planned to be used for the candy business was used for other consumptive purposes. There are properties that are consistent with the results of the interview between Weton Tuesday Wage's explanation according to Doyodipuro's book (2016) where the wage Tuesday symbolized by fire and cattle has the nature of trying to be kind, but always fails and is ready to help others and the feeling of being open and willing he will do anything or the instructions of the person he trusts or trusts. The debtor repeatedly feels uneasy if there are friends who ask for help so that they will always help. However, it does not take into account the profit and loss in providing such assistance. In the phenomenon that occurs, the debtor is kind enough to lend the remaining credit of Rp. 8,500,000, which leads to the return of the money. In addition, according to Doyodipuro (2016) the debtor will do anything or the instructions of the person he trusts and this is proven if the debtor has lent money to his friend who will be used for the tobacco business which also leads to loss due to overconfidence.

\subsection{Debtor with Weton Kamis Legi}

People born in this weton tend not to have sincere, irritable and irritable kindness. They will only be generous when they get flattery. In addition, they are not good at making friends. This friendship relationship that Weton has always does not last long.

In terms of finance, they have a good fortune and are also generous. In addition they seemed to be helpful, and not stingy with others. But they do not have calculations in terms of financial arrangements. Spending money from Weton tends to be wasteful and has very prominent peroual characteristics. In addition they are people who are easily influenced, easily tempted and carried away by the atmosphere

The extravagant and loyal nature of the dominant is one of the causes of a person's bad financial affairs. In addition, the easy temptation and influence make them easy to make decisions including 
spending money that is actually not needed. This makes the priority scale loose in terms of the use of funds in daily life, so that the bank's obligations are neglected.

The majority of debtors in weton Thursday legi were born on the Galungan region as on Saturday pound. As explained earlier, this Wuku is the 11th Wuku shaded by Dewa Bathara Kamajaya, so it has the character of being sincere and able to destroy sad, humble people. Those born in Wuku Galungan generally have beautiful faces and are easy to approach the opposite sex.

One of the debtors with Weton Kamis Legi who was born there is Endang Rahayu. Just like the previous debtor on behalf of Siswono, if the person concerned does not become a credit applicant, but who manages the proceeds from credit and matters with the Bank. Submission of credit in the name of her husband, Achmad Prihardiyono with a ceiling of Rp. 200,000,000 (two hundred million). The author said how the chronology of the arrears of credit installments and the debtor began to tell,

"I am a furniture business, I have 22 (twenty two years), I sent the market to Bali. In the past many were furniture businesses, now I am the only one who still survives"

The author further stated how many ceilings were taken,

"I took a Rp. 200,000,000 (two hundred million) rupiah ceiling. And the mistake I was on making the raw material wood and one in monitoring. If the wood I was scrap wood. At that time there were indeed many orders of $R p 1.2$ billion. So that at that time the wood had to come a lot and there were also a lot of workers who came around 12 people to work on the order. Then I roll up. And having a debt to the wood supplier is around Rp. 253.000,000, (two hundred fifty three million) rupiah. There is a current Bank debt at about $R p$ 200.000.000 , - (two hundred million) rupiah. The point of my total debt of Rp 600 .000.000, - (six hundred million) rupiah. But now Thank God stay this bank's wrote and debt leftover wood to Rp 30,000,000 (thirty million)"

Based on the information from the interview above, the authors conclude that the main factor is the occurrence of credit arrears due to errors in the collection of raw materials and the supervision of wood logs. Respondents felt cheated by wood raw material suppliers from the City of Kraksaan. Where is the type of wood which is not suitable for furniture. Given that the debtor has owed and paid the wood supplier Rp. 253,000,000. In addition, the debtor also has a worker who is experiencing personal problems where at the time of working on cutting wood has failed 3 times. In accordance with Doyodipuro's book (2016) that Weton Kemis Legi has a wind and cat symbol where one of the characters is often cheated because of carelessness. In the debtor default, this can be seen when the debtor trusts the wood supplier and in the end the wood does not match the quality that should be. So that for this incident, respondents experienced financial difficulties in running their business.

\subsection{Debtor with Weton Saturday Legi}

Like weton Wednesday Pon, this weton is also dominated by Bolo wuku. Wuku Bala or Bolo is symbolized by cypress trees, which are like charity but for glory, and are willing to give protection only to those who want to obey. Wuku that is sheltered by Bathari Durga tends to have a troublesome nature, is not afraid of anyone including employers or superiors. People who are born in this period tend to be easy to approach officials, but have an arrogant nature (Gudel, 2015).

This time tends to bring bad character to people who were born at that time. Courageous and ignorant nature of the debtor born in this period is the root of the debtor's low desire to fulfill his obligations. Although he has been blessed with abundant fortune, his arrogant nature makes him forget the side of the bank - the party who has provided assistance. Weton Saturday Legi Wuku Bolo has a Tungle (leaf) paringkelan. Ringkel is the day of the apers leaves, so it is considered a good day to find food and gather medicines. People born in this vulnerel tend to be peaceful and have good relationships. But like the mouse symbol, the birth of the fronds of the leaves is often subject to slander.

The next time that dominates Weton isWuku Julungpujut. Julungpujut is the 15th time that this is shaded by Dewa Bathara Guritna. In general, those born in this age like the crowd have good words, have a big passion and a strong degree. Even though they have great determination and will, they tend to have complex ways of thinking. In terms of finance, the fortune they have tends to be quiet even though not much. 
Paringkelan from Saturday Legi Julungpujut is Wurukung or ringkel Sato. This is the day of telling 4legged animals, so that people of old times used the day of Sangko to hunt. Humans born in this vulnerel are influenced by strong, courageous, but careless and under-calculated traits. In addition to Wuku Julungpujut, the highest number of debtors with weton Saturday Legi wasWuku Tolu. In general, the person born in this book has a depicted character like Dewa Bathara Bayu who is straightforward, assertive, keeps the position of not wanting to be polite and generous (Gudel, 2015). However, the character of someone who is portrayed as a "front man" tends to exhibit wealth and be arrogant.

The author conducted an interview with Siswono who was a person with weton Saturday Legi. The person concerned is not a bank debtor, but is involved in the management of the credit funds received and the affairs of the loan payable with the Bank. He uses the data of his wife Emy Sulistyowati who works as a civil servant to apply for credit from the Bank. The author asks for the chronology of the bad credit, then the debtor explains:

"In the past I had a cracker business and my business was already running, it was smooth, there was an initiative to develop a business. Then I borrowed from the Bank through the name of my wife's submission, but the money and everything was the same as my bank's managing business."

While holding and showing samples of crackers produced, then the concerned continues the story:

"This cracker business is smoothly, I supply to the regions these campuses must have finished in the afternoon. The rotation is fast. Because my employee has a lot. Then if the production here is not enough, so I used to borrow money from the bank to plan to buy the land there and then build a warehouse for this cracker business. "

While serving coffee, the author asks how much the requested ceiling is:

"I am here (the Bank) taking Rp. 600,000,000 (six hundred million). I originally needed 1 billion mas. If all of the application values are realized, the submission is in the bank. So my remaining Rp. 400,000,000 (four hundred million), get it from the sale of my car. And my friend promises me if I want to borrow money for the business operation.

Then the debtor continues the story about the credit plan:

"It used to be that the plan was for Rp.600,000,000 (six hundred million) to buy land for businesses to make it bigger. I took a credit term for 10 years. At the beginning of the realization on April 7, 2015, it means up to 2025. Well, I was deceived by my friend, so I need 1 billion, the remaining Rp.400,000,000 (four hundred million) that I was promised my friend would buy my car and lending money didn't work, it's still complicated. So I have no money to play business. The money from the Bank has gone up Rp. 600,000,000 (six hundred million) to buy the land, mas.

The author asks whether previously taking credit at the Bank currently has a credit facility at another Bank before, then the debtor answers:

"I was before at other Bank. And my installments are smooth at other Bank. And frankly, because the crackers are amazingly fast in their business, then I take them again at the current Bank. So it's the same as 2 bank installments. "

The author pays attention from the results of the interview that there is one cause of arrears in debtor credit installments, namely the absence of funds used to carry out a new business plan which is located on land and warehouses that have just been purchased with a credit of Rp. 600,000,000 (six hundred million). Operational funds amounting to Rp. 400,000,000 (four hundred million) which should be promised by his friends from the day of motorcycle sales and loan money, but not fulfilled, so that in this case the debtor feels cheated by his partner. Doyodipuro (2016) explains that people who were born on Saturday Legi tends to be willpower and hard-working. Often maligned and many friends, but there are also many enemies and are bullied by people. In this phenomenon, the debtor is included in being bullied by others by being deceived into the promise of giving loan money and purchasing a car belonging to the debtor. Thus, the debtor is unable to run his business and experience congestion. 


\subsection{Character Relationship Based on Weton with Allowance for Impairment Losses (LLP)}

According to PSAK 55 (2015) paragraph 59 explains that a financial asset or group of financial assets is reduced in value and impairment loss has occurred if there is objective evidence of impairment as a result of one or more events that occur after the initial recognition of the asset, and the event has an impact on the estimated future cash flows of a financial asset or group of financial assets that can be estimated reliably. In this study financial assets are classified as KYD or Loan and Recivables. Given loans are impaired because the debtor does not make installment payments on a regular basis, so that the estimated value of the collection of future loans is less than the carrying amount before impairment.

The entiteny first determines that there is objective evidence of individual impairment of financial assets that are individually significant, and individually or collectively for financial assets that are not individually significant. The entiteny has the authority to classify the category of impairment based on clear, rational reasons and pay attention to all risks of credit exposure. In this study, the author assumes that a decrease in the value of the credit given individually in estimating future cash flows. (PSAK 55, 2015)

Estimation of the value of future cash flows based on objective evidence that the Loans Given that are impaired are derived from observable data regarding adverse events. Based on the results of observations and interviews with debtors, the researcher saw a default or delinquency in payment of principal or interest, as well as the level of seriousness and debtor's ability stated in the call report, namely the promise of payment from non-performing debtors and used as one of the new cashflow forming componentswhich will determine the amount of LLP for the credit that contains the date of the promised payment, the amount to be paid, the sign the debtor's hand above the stamp and photo if possible. Data originating from the call report indicate a measurable impairment of estimated future cash flows from Given Loans.

The cause of impairment losses are measured as the difference between the asset's carrying amount and the present value of estimated future cash flows discounted using the original effective interest rate of the asset. The amount of recorded assets is reduced either directly or by using a reserve account called the Allowance for Impairment Losses (LLP). The amount of loss incurred is recognized in profit or loss. Recognition of estimated LLP considers all relevant information available. Reserves that have been formed individually in accordance with cashflow from the results on the spot which is done first and if however, the debtor does not fulfill the payment agreement, the Bank is obliged to make a return visit to the debtor to make a new call report on the debtor's promise, and provide a poor justification of the previous cashflow. Likewise, if the debtor can be found and can fulfill the promise of payment, then the bank has the right to provide an adjustment for the promise of the debtor to be worse as long as there is a rational reason and objective analysis written in the call report as a record or document;

Based on the results of the interview that the debtor with Weton Wednesday Pon on behalf of Judy who in December 2017 had promised to make payment in April 2018, but the person concerned did not make a payment. After further searching, it turns out that the debtor is experiencing financial disruption because the loan proceeds are used for non-allocation purposes. According to Mrs. Endang's interpretation that " those who wed Wednesday Pon are so royal that they do not have a priority scale in financial matters". This is evident from the interview of Ms. Mami that "those who say that often send their committees to make worship visits using personal money". Mbah Gudel also added that if you need to see my wuku and paringkelan from Wednesday Pon that is Wuku Bala who explains if they "like charity but for glory, tend to have troublesome nature, not afraid of anyone" . In fact, Mbah Gudel argues if the Bala bring the worst character compared to other women. In the case of paringkelan, the debtor has a Paningron parcel, which those born with this frail have a tendency to cheat. Seeing the behavior of the debtor Judy is a manifestation of the weton he has so that influences his daily actions. The act of loyalty to the community will automatically affect the financial condition of the business so that disruption to the cash flow of the business that is owned results in not being able to fulfill the financial obligations in the form of debt to the Bank. Furthermore, in accordance with the results on the spot the bank evaluates the decline in value according to call report information and interviews. The Bank estimates the amount of credit losses and the recoverable amount based on the identification of future cash flows. Officer interpret call 
report in April 2018 that has been denied and observable data analysis that indicates the value of impairment, so that the debtor on behalf of Judy Sukardjo has an initial outstanding of Rp 2,500,000,000 with a period of 12 months starting from 9 September 2016 until by 9 September 2017 and due to their nature in accordance with the opinion of Doyodipuro (2016) per month of April 2018 it has formed a perfect LLP of $100 \%$ is Rp 2.500.000.000 and the Bank recognizes as the account "Losses" in profit loss and as "Allowance for Impairment Losses" in the statement of financial positionand cancel the interest income that has been recognized and has not received payment .

Debtors with Weton Wednesday Pon others on behalf of Nonong Holiyatin that on the first visit is willing and promise to make payments overdue loans and agreed the payment is made every month on a regular basis as outlined in the call report $\mathrm{Rp} 1.500 .000,00$. On visit the two debtors cannot be found and until the meeting the three debtors deny their promise to pay Rp. 200,000.00 per day. According to the author, this is a debtor's trick so that the bank's billing staff does not make billing every day due to location and cost factors. In accordance with the character of the debtor who does not want to return the favor indicates that the debtor does not wish to repay the loan as much as possible. PSAK 55 (2015) explains that the formation of LLP individually in accordance with cash flow from the results on the spot that carried out in the previous period and if the debtor does not fulfill the payment agreement. In this study, installments on April 2018 visits amounted to Rp. $1,500,000.00$ and decreased to Rp. 200,000.00 because the debtor character did not fulfill his promise. In addition, according to Doyodipuro's (2016) explanation regarding the nature of debtors who do not

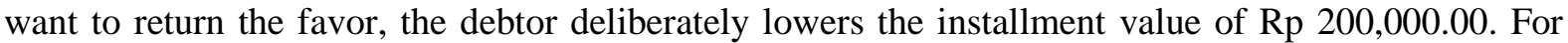
the characters and events, the bank gave a less good justification for future cashflow estimates and formed LLP per May 2018 amounting to Rp 149,682,594,00.

According to the Indonesian Banking Accounting Guidelines (PAPI) in 2008 thattheir realization of liquefaction credit, it appears the account Loans on the asset side and automatically establish LLP as the impact of business risks it must back up either collectively or individual. Individual LLP is calculated by predicting the ability of payments from future debtors. Respondents on behalf of Endang Rahayu who borrowed money amounting to Rp 200,000,000 with a period of 3 years or 36 months where the respondent experienced arrears during the 12th month installment. Billing staff made on-the-spot visits to inspect the problem of credit arrears and produce a call report containing the inability to pay in the next few months. The call report is an objective evidence that will be used as an estimate of the ability of debtor payments by adjusting the credit period. When the author visits in April 2018, the debtor promises the following month on the 27th to make an installment of Rp. 2,500,000.

Bambang Sumantri, who was born in Weton on Saturday Pon, experienced credit delinquency due to bankrupt tile making business. The bankruptcy of the business is because the debtor has a lazy workforce. This means that the debtor can be said to be bullied by people. This has an impact on the formation of a perfect LLP of Rp. 350,000,000. The establishment of the full LLP is because the loan maturity period has been exceeded. What experienced by Bambang Sumatri is an indirect impact of the tendency of the character possessed. Debtors with other Pon Weton Saturday that Tommy Bohan thehappy others and pleases his family. However, his character is brave by not thinking about family financial problems that result in credit defaults (Doyodipuro, 2016). Due to the conditions experienced by the debtor, the Bank has established a LLP amounting to Rp. 51,772,929.00 from the initial outstanding of Rp. 220,000,000.00

Doyodipuro (2016) states that wage Tuesday which is symbolized by fire and cow that has the nature of trying to be kind, but always fails and is ready to help others and a sense of openness and willingness he will do anything at the direction of the person trusted or believe. This is seen in one of the debtors, Rofiq Fauzi. Instead of credit money used for making candy, what happens is that there is no control over the flow of money to various destinations. The nature of the debtor who likes to lend money or goods that results in disruption of the debtor's credit installments. On this matter, the bank formed a LLP amounting to Rp. 20,129,643.00 with a period of 36 months. What the debtor Rofiq Fauzi experienced was quite different from that of Slamet Joyo, it was because of the different wuku and paringkelan of the debtor. The author did not find a match between the nature of the debtor and the explanation of the weton-based character proposed by Doyodipuro (2016). The debtor's failure in credit matters is because the person failed in running for the village head for 2 (two) election periods. 
Respondents on behalf of Endang Rahayu who borrowed Rp. 200,000,000 with a period of 3 years or 36 months in which the respondent experienced arrears during the 12th installment. Billing staff made on-the-spot visits to inspect credit delinquency issues and produce call reports. which contains inability to pay in the next few months. Call report this is an objective evidence that will be used as an estimate of the ability of debtor payments by adjusting the credit period. When the author visits in April 2018, the debtor promises the following month on the 27th to make an installment of Rp. $2,500,000$. On the cash flow, analysts estimate cash flows that will come in forming LLP amounting to Rp 99,253,928.97. The LLP was formed because the debtor was deceived by a supplier of wood raw materials that did not match the quality.

Debtors who also failed in repaying their debts to the Bank were also experienced by Siswono who was also deceived by his partner on the promise to provide operational money. Weton debtor falls on a Saturday Legi where according Doyodipuro (2016) that people born on Saturday Legi tends to bewillpower and hard-working. It is often slandered and not many people, but there are also many enemies and people who have been bullied. In this phenomenon, the debtor is included in being bullied by others by being deceived into the promise of giving loan money and purchasing a car belonging to the debtor. So that on this phenomenon by adjusting the credit period for 120 months, credit analysts reserve a loss of $\mathrm{Rp} 431,462,515.12$.

\section{CONCLUSiONS AND Suggestions}

In this study it can be concluded that weton has relevance to the character of an individual. This is because weton is actually also a matter that is prepared scientifically and through a long-term process. On the character, it also has an impact on the actions of someone who in this study is a debtor. Based on the results of interviews and literature studies, researchers see that there are direct and indirect impacts that can lead to credit defaults.

According to the Regulation of the Financial Services Authority (FSA) Number 42 / POJK.03 / 2017 dated July 12, 2017 concerning the Obligation to Compile and Implement Bank Credit or Financing Policies for Commercial Banks, it states that the Bank must be able and have confidence in the indepth analysis of the candidates' intentions, intentions and abilities. the debtor in completing his obligations as agreed. Research is expected to provide an overview implications related practices, inputs, and the benefits to which the credit analysts in analyzing existing or prospective borrowers to use science Weton pawukon particular debtor can be seen from the date of birth of the debtor and merelevansikanya with credit payment behavior.

\subsection{Limitations}

This study uses the basic theory of -teori described in IAS 55 Financial Instruments specifically in the classification of the formation of Allowance for Impairment Losses (LLP) Individual who recognize credit losses during the credit loss event occurred (incurred loss). PSAK 55 will be replaced by PSAK 71 Financial Instruments which in September 2016 has been published an exposure draft (ED)and effective as of January 1, 2020. In PSAK 71 uses impairment approach with Expected Credit Loss (ECL) whereby the entiteny must immediately recognize the impact of expected credit loss changes after initial recognition by considering reasonable and supported future information (reasonable supported forecast). However, this will be a constraint and a challenge for financial service business players because in conducting credit risk analysis and expectations of credit loss measurement there is no strong information and basis available.

\subsection{Suggestion}

According to PSAK 71, one of nine information that influences the occurrence of changes in default risk, namely behavior and payment status. Therefore, further research is expected to be able to make modeling and / or scoring in default risk, especially information on debtor payment behavior that can be seen comprehensively from the debtor weton that reflects the character. Thus, later debtor weton is able to be an indicator of default risk and a reduction in the amount of expected credit allowance.

\section{REFERENCE}

[1] 1998, U. N. T. Tahun 1998 Tentang Perubahan Atas Undang-Undang Nomor 7 Tahun 1992 Tentang Perbankan. Lembaran Negara Nomor, 182. 
[2] Abdou, H. A., \&Pointon, J. (2011). Credit Scoring, Statistical Techniques, And Evaluation Criteria: A Review Of The Literature. Intelligent Systems in Accounting, Finance and Management, 18(2-3), 59-88.

[3] Ahmed, A. S.,Takeda, C., \&Thomas, S. (1999). Bank Loan Loss Provisions : A Reexamination Of Capital Management, Earnings Management, And Signaling Effects. Journal of Accounting And Economics, 28(1), 1-25.

[4] Andreou, P. C.,Cooper, I.,Louca, C., \&Philip, D. (2017a). Bank loan loss accounting treatments, credit cycles and crash risk. The British Accounting Review.

[5] Andreou, P. C.,Cooper, I.,Louca, C., \&Philip, D. (2017b). Bank Loan Loss Accounting Treatments, Credit Cycles, And Crash Risk. The British Accounting Review.

[6] Angst, J., \&Scheidegger, P. (1976). Signs Of The Zodiac And Personality. Sozial und Praventivmedizin, 21(1), 39-41.

[7] Balasubramanyan, L.,Zaman, S., \&Thomson, J. B. (2014). Are Banks Forward-Looking In Their Loan Loss Provisioning ? Evidence From The Senior Loan Officer Opinion Survey (SLOOS).

[8] Bischof, J.,Daske, H.,Elfers, F., \&Hail, L. (2016). A Tale Of Two Regulators : Risk Disclosures, Liquidity, And Enforcement In The Banking Sector.

[9] Boulila Taktak, N.,Ben Slama Zouari, S., \&Boudriga, A. (2010). Do Islamic banks use loan loss provisions to smooth their results? Journal of Islamic Accounting and Business Research, 1(2), 114-127.

[10] Burrell, G., \&Morgan, G. (1979). Sociology Paradigm And Organisational Analysis: Elements Of The Sociology Of Corporate Life: Portsmouth: Heinemann.

[11] Burrell, G., \&Morgan, G. (2017). Sociological paradigms and organisational analysis: Elements of the sociology of corporate life: Routledge.

[12] Carrizosa, R., \&Ryan, S. G. (2016). Borrower Private Information Covenants And Loan Contract Monitoring.

[13] Chua, W. F. (1986). Radical developments in accounting thought. Accounting review, 601-632.

[14] Curcio, D., \&Hasan, I. (2015). Earnings And Capital Management And Signaling : The Use Of Loan Loss Provisions By European Banks. The European Journal Of Finance, 21(1), 26-50.

[15] Danandjaja, J. (1980). Metode Penelitian Kepustakaan. Anthropologi Universitas Indonesia, No 52.

[16] Doyodipuro, K. H. (2016). Horoskop Jawa - Misteri Pranata Mangsa. Dahara Prize, Edisi Revisi.

[17] Fonseca, A. R., \&Gonzalez, F. (2008). Cross-country determinants of bank income smoothing by managing loan-loss provisions. Journal of Banking \& Finance, 32(2), 217-228.

[18] Gudel, D. B. M. (2015). Mengitung Hari : Aneka Sistim Penanggalan Wong Jawa Dari Masa Ke Masa. UPT Perpustakaan Proklamator Bung Karno: Perpustakaan Nasional Republik Indonesia.

[19] Gunasasmita, R. (2009). Kitab Primbon Jawa Serbaguna: Penerbit Narasi.

[20] Julien, H. (1996). A Content Analysis Of The Recent Information Needs And Uses Literature. Library \& Information Science Research, 18(1), 53-65.

[21] Kasmir. (2007). Manajemen Perbankan: Raja Grafindo Persada.

[22] Kasmir. (2012). Dasar-Dasar Perbankan Edisi Revisi: PT Raja Grafindo Persada, Jakarta.

[23] Kattsoff, L. O. (2004). Pengantar filsafat, penerjemah: Soejono Soemargono. Yogyakarta: Tiara Wacana.

[24] Laeven, L., \&Majnoni, G. (2003). Loan Loss Provisioning And Economic Slowdowns : Too Much, Too Late ? Journal Of Financial Intermediation, 12(2), 178-197.

[25] Marton, J., \&Runesson, E. (2017). The Predictive Ability Of Loan Loss Provisions In Banks-Effects Of Accounting Standards, Enforcement, And Incentives. The British Accounting Review, 49(2), 162-180.

[26] Messai, A. S., \&Jouini, F. (2013). Micro And Macro Determinants Of Non-Performing Loans. International journal of economics and financial issues, 3(4), 852.

[27] Minnis, M., \&Sutherland, A. (2017). Financial Statements As Monitoring Mechanisms : Evidence From Small Commercial Loans. Journal of Accounting Research, 55(1), 197-233.

[28] Moleong. (2009). Metodologi Penelitian Kualitatif. Bandung : PT Remaja Rusda Kary.

[29] Muhadjir, N. (2001). Filsafat Ilmu, Positivisme, Post Positivisme dan Post Modernisme. Yogyakarta: Rake Sarasin.

[30] Onali, E., \&Ginesti, G. (2015). New Accounting Rules For Loan Loss Provisions In Europe : Much A Do About Nothing?

[31] Ozili, P. K., \&Outa, E. (2017a). Bank Loan Loss Provisions Research : A Review Borsa Istanbul Review.

[32] Ozili, P. K., \&Outa, E. (2017b). Bank Loan Loss Provisions Research: A Review. Borsa Istanbul Review

[33] Packer, F., \&Zhu, H. (2012). Loan Loss Provisioning Practices Of Asian Banks. 
[34] Pellegrini, R. J. (1973). The Astrological "Theory" Of Personality: An Unbiased Test By A Biased Observer. The Journal of psychology, 85(1), 21-28.

[35] Purwanti, L. (2015). Refleksi Perilaku Pengguna Laporan Keuangan Atas Praktik Manajemen Laba Dalam Perspektif Weton. Jurnal Akuntansi Multiparadigma, 6(3), 362-372.

[36] Rajan, R., \&Winton, A. (1995). Covenants And Collateral As Incentives To Monitor. The Journal of Finance, 50(4), 1113-1146.

[37] Ritzer, G., \&Goodman, D. J. (2004). Teori sosiologi modern. Jakarta: Prenada Media, 121.

[38] Sari, R. W. (2014). Kemauan Membayar Pajak Wajib Pajak Orang Pribadi Dilihat Dari Sisi Weton Wajib Pajak. Universitas Muhammadiyah Surakarta.

[39] Sawarjuwono, T., \&Kadir, A. P. (2004). Intellectual Capital: Perlakuan, Pengukuran dan Pelaporan (Sebuah Library Research). Jurnal akuntansi dan keuangan, 5(1), pp. 35-57.

[40] Silverman, B. I., \&Whitmer, M. (1974). Astrological Indicators Of Personality. The Journal of psychology, 87(1), 89-95.

[41] Spranger, E. (1928). The Tipe on Man The Psychology and Etnich of Personality. Max Niemeyer Verlg, Hall

[42] Sudharta, T. R. (2001). Kalender 301 tahun (tahun 1800 s/d 2100): PT Balai Pustaka.

[43] Sugiyono. (2015). Metode Penelitian Manajemen. Bandung : Alfabeta, CV.

[44] Sutherland, A. (2016). The Economic Consequences Of Borrower Information Sharing : Relationship Dynamics And Investment.

[45] Tedyono, R., \&Mahadwartha, P. A. (2018). Management's Shio And Ownership To Firm Performance. 15th International Symposium on Management.

[46] Thamrin, A., \&Tantri, F. (2012). Bank Dan Lembaga Keuangan. Jakarta: Rajawali Pers.

[47] Thomas, L. C. (2000). A Survey Of Credit And Behavioural Scoring : Forecasting Financial Risk Of Lending To Consumers. International journal of forecasting, 16(2), 149-172.

[48] Tjakraningrat, K. P. H., \&Soemodidjojo, R. (1968). Kitab Primbon Betaljemur Adammakna: Soemididjojo Mahadewa.

[49] Wall, L. D., \&Koch, T. W. (2000). Bank Loan Loss Accounting : A Review Of Theoretical And Empirical Evidence. Economic Review - Federal Reserve Bank of Atlanta, 85(2), 1.

[50] Wijoto. (1972). Tarich Caka Djawa Dengan Pranata Mangsa.

[51] Zhao, Q. (2016). Do Political Connections Affect Bank Loan Loss Provision Reliability? Accounting and Finance Research, 5(3), 118.

Citation: Dwi Rendra Adi Putrawijaya, Basuki. "Reflection of Pay Failed Debtor Behavior Based on Weton Based Characters". International Journal of Managerial Studies and Research (IJMSR), vol 6, no. 11, 2018, pp. 15-29. doi: http://dx.doi.org/10.20431/2349-0349.0611002.

Copyright: (C) 2018 Authors. This is an open-access article distributed under the terms of the Creative Commons Attribution License, which permits unrestricted use, distribution, and reproduction in any medium, provided the original author and source are credited. 